\title{
Isolation, Serotyping and Molecular Detection of Bovine FMD Virus from Outbreak Cases in Aba'ala District of Afar Region
}

Teshager Dubie Tegegne ( $\nabla$ teshagerdubie@su.edu.et )

Samara University https://orcid.org/0000-0001-7026-6267

Tsedale Amare Mengiste

Samara University

Research article

Keywords: Afar, Cattle, FMDV, Molecular Detection, Outbreak, Serotyping

Posted Date: December 17th, 2020

DOI: https://doi.org/10.21203/rs.3.rs-28928/v2

License: (c) (i) This work is licensed under a Creative Commons Attribution 4.0 International License.

Read Full License 


\section{Abstract}

Background: Among the top listed economically important transboundary livestock diseases of cattle, foot and mouth disease (FMD) is the leading bottleneck in livestock production and productivity in Ethiopia. On the basis of FMDV active outbreak cases, a cross sectional study was undertaken to collect samples from January, 2019 to March, 2020 intended for isolation, serotyping and molecular detection of FMDV in the study district. Purposive sampling method was applied to select the study area for the reason that the presence of current active FMD outbreak case report during the study period. Totally, 27 FMD suspected clinical samples were collected from clinically affected study population during field outbreak. Out of 27 samples, 18 of them were inoculated on cultured Baby hamster kidney (BHK-21) monolayer cells and all 27 samples were tested using conventional RT-PCR and sets of specific universal primers. Finally, the PCR products were visualized with UV illumination and imaged with gel documentation system.

Results: The current study result revealed that out of 18 clinical samples subjected to virus isolation, $72.2 \%(n=13)$ of these cultures exhibited FMDV induced cytopathic effect (CPE) and the identified serotype was SAT-2 FMD virus. Out of 27 clinical samples tested by conventional RT-PCR, only 12 FMDV samples were found to be FMDV positive by universal primers. Out of 27 clinical samples detected by conventional reverse transcription polymerase chain reaction (RT-PCR), only 12 FMDV samples were found to be FMDV positive by universal primers.

Conclusions: Our study finding indicated FMDV is prevalent in the study area and FMDV serotype SAT-2 was the causality for the outbreaks of the disease in the study area. Hence, region wise regular FMD outbreaks investigation, further phylogenetic analysis and vaccine matching field isolates should be carried out to know in depth data about FMDV serotypes and topotypes involving in afar region of Ethiopia for effective vaccine development and control of the disease.

\section{Background}

Ethiopia owns the largest livestock population in Africa with an estimated animals' number of 59.5 million heads of cattle, 30.5 million sheep, 30.3 million goats and 54.5 million chickens [1]. The role of livestock resource to the nation's economy is expected at $19 \%$ from the total GDP, $45-48 \%$ of the agricultural GDP and about $20 \%$ of the country's export incomes [2]. Moreover, the livestock sector plays a vital role in the livelihood of popular of human population in Ethiopia as a source of meat, milk, drought power and income. The contribution of livestock to the country's economy primarily in terms of foreign currency gains is via export of live animals, meat and skin and hides [3]. In spite of possessing such huge amount of livestock resources, the country couldn't utilize the sector as a totally as a result of extremely rampant livestock diseases, absence of appropriate disease management strategy as well as less attention from government side $[4,5]$. 
Livestock diseases remain the most vital impediments to the development of the sector through reducing production and productivity that could ultimately affect regional, national and international trade in live animal and animal products' [4]. According to [6] livestock diseases cause major economic losses to the peasant farmer and pastoralists in Ethiopia amounting to hundreds of millions of birr every year. Approximately, annual mortality rates attributed to these livestock diseases is computed to be $9-12 \%$ for cattle herds, $15 \%$ and $13 \%$ sheep and goat flocks respectively [7]. Among livestock diseases hindering production and productivity of the sector, foot and mouth disease (FMD) is the most known economically important transboundary viral disease of cattle in Ethiopia [6, 8]. Foot and mouth disease (FMD) is an extremely contagious and extremely infectious livestock disease of all cloven hoofed animals. It is the world's most important cattle disease and accountable for vast worldwide drop of livestock production and encouraging national and global business impediments for livestock and livestock products $[4,9]$. Foot and mouth disease (FMD) is caused by FMD virus (FMDV) that comes under the genus Aphthovirus within the family Picornaviridae. Clinically, FMD is manifested by fever, loss of appetite, salivation, vesicular eruptions in mucosa of the mouth, skin of the inter-digital spaces and coronary bands of the feet and teats, and sudden death of young stock $[10,11]$. As of the international organization for animal health (OIE), FMD ranks first among globally important notifiable infectious livestock diseases because of exports of infected livestock and livestock products could easily cause outbreak in countries that are previously free from FMD outbreak cases and transboundary distribution nature of the disease [12]. Pastoralists are highly impacted by direct and indirect effects of FMD as their lives are straightforwardly dependent on livestock production $[6,13]$. Generally, studies conducted on FMD serostatus previously indicated the presence of the disease in various areas of the country with seroprevalence that ranges from $8.18 \%$ to $44.2 \%$ in different part of the nation $[14,15]$.

Foot and mouth disease virus (FMDV) has seven immunologically, antigenically and genetically distinct serotypes (O, A, C, Asia 1, Southern African Territories (SAT)-1, SAT-2 and SAT-3) that cause indistinguishable clinical disease [16]. Within these serotypes, over 65 diversity of topotypes, genetic lineages and strains have also been identified using biochemical and immunological tests. Currently, five FMDV serotypes (O, A, C, SAT-1 and SAT-2) are identified and documented in Ethiopia $[3,4,17,18]$. The serotypes also differ in their geographical distribution over the world as well as in many regions of the country $[3,19]$. According to [20] retrospective study finding, FMDV serotypes $0, A$, SAT 2, and SAT 1 were identified as the causative serotypes for outbreak cases occurring during the study time 2007-2012. While 0 was the dominant serotype, SAT 2 was the serotype which indicated raise in comparative frequency of occurrence $[3,20]$. Prompted investigation and detection of FMDV serotypes during outbreak was highly crucial to determine the origin of infection and to use appropriate vaccine [21].

Despite occurrence of several outbreaks of FMDV in the afar region, there is no even single documented information to know about the disease current serostatus, serotypes circulating in the region in general and the study area in particular. To develop effective control measures of FMD, determining its serostatus, virus isolation and identification of the serotype(s) circulating in a particular area would have paramount importance. Moreover, having a detailed knowledge on the specific serotypes circulating in a particular area has paramount importance for companies to target for each specific FMDV serotype for 
effective vaccine development in steady of rely on production of trivalent vaccine for serotype $O, A$ and SAT-2.Therefore, the present study was intended for isolation and serotype identification of FMDV from outbreak cases in Aba'ala district of Afar region from January, 2019 to March, 2020 in Ethiopia.

\section{Results}

\section{Clinical Examination of FMD Outbreaks}

In this outbreak investigation and sample collection, characteristic clinical signs of FMDV in the study population were salivation, lameness, vesicle formations on oral cavity, profuse salivation and interdigital vesicles. Suggestive lesions of FMD on the mouth contained destructions and sores on the upper and lower pad area and tongue, while feet abrasions consist of wearing away on the inter-digital space. Outbreak affected cattle were disinclined to travel and lagging overdue the healthy study population and deny for feeding.

\section{FMD Virus Isolation}

The Current cell culture based FMD virus isolation result revealed that out of 18 suspected clinical samples processed and cultured, $72.2 \%(n=13)$ representative samples were exhibited morphological alterations (FMDV cytopathic effect (CPE) on BHK-21 cells; while the other clinical samples of FMDV $(n=9)$ did not inoculated on the cells because these samples were collected from same outbreak in the study areas. Out of 13 FMD clinical samples that showed cytopathic effect on BHK-21 cells, 33.3\% $(n=6)$, $22.2 \%(n=4)$ and $16.7 \%(n=3)$ were epithelial tissues, vesicular fluid and swab samples respectively. These FMD positive clinical samples were characterized primarily by a quick sloughing of BHK-21 monolayer cells and these sloughed cells were roughly round, swelling and formed singly in shape (Figure 1). As time progress, there was sloughing of cells or monolayer detachment from the wall of cell culture flask and even some cells were severely damaged within $72 \mathrm{hrs}$ after inoculation and finally cell death that indicates the presence of virus. However, samples that did not show CPE do not induce morphologic changes of cell. Whole cell sloughing of the pane was regularly observed after $48 \mathrm{hrs}$ of cell injection. Figure 3 below indicated illustrates the circular and lysis (CPE) of BHK-21 cells injected by the virus and uninfected ones.

\section{Serotyping of FMD Virus Isolates}

FMD Serotyping was executed using 13 positive samples by antigen detection sandwich ELISA intended for identifying the serotypes involved in the outbreaks. Out of 13 positive FMDV clinical samples, only 9 samples were identified to be serotype SAT-2. Therefore, the current study finding revealed that SAT-2 serotype could be the possible causes of the disease detected in the outbreak areas as depicted (table 2). All outbreaks confirmed samples collected from both kebeles of the same district were identified as SAT-2 serotype. In conclusion, outbreaks of the study district (subunits) was occurred due to FMD serotype SAT2 . 
Table 2: Serotyping results of FMD virus isolates at NVI, Bishoftu Ethiopia

\begin{tabular}{|lllllll|}
\hline No & $\begin{array}{l}\text { Sample } \\
\text { code }\end{array}$ & Sample type & Sex & $\begin{array}{l}\text { kebele level } \\
\text { outbreaks }\end{array}$ & Species & $\begin{array}{l}\text { Serotyping } \\
\text { Results }\end{array}$ \\
\hline 1 & E-M-E1 & Epithelial tissue & Male & Erkudi & Bovine & SAT-2 \\
\hline 3 & E-M-V2 & $\begin{array}{l}\text { Vesicular } \\
\text { sample }\end{array}$ & Male & Erkudi & Bovine & SAT-2 \\
\hline 4 & E-M-S3 & Swab sample & Female & Erkudi & Bovine & - \\
\hline 5 & E-F-V5 & $\begin{array}{l}\text { Eesicular } \\
\text { sample }\end{array}$ & Female & Erkudi & Bovine & SAT-2 \\
\hline 6 & E-F-S6 & Swab sample & Female & Erkudi & Bovine & - \\
\hline 7 & E-F-E7 & Epithelial tissue & Female & Erkudi & SAT-2 \\
\hline 8 & E-F-V8 & $\begin{array}{l}\text { Vesicular } \\
\text { sample }\end{array}$ & Female & Erkudi & Bovine & SAT-2 \\
\hline 9 & E-F-E9 & Epithelial tissue & Female & Erkudi & SAT-2 \\
\hline 10 & E-F-V10 & $\begin{array}{l}\text { Vesicular } \\
\text { sample }\end{array}$ & Female & Erkudi & Bovine & - \\
\hline 11 & E-M-E11 & Epithelial tissue & Male & Erkudi & Bovine & SAT-2 \\
\hline 12 & E-F-S12 & Swab sample & Female & Erkudi & Bovine & SAT-2 \\
\hline 13 & E-F-E13 & Epithelial tissue & Female & Erkudi & Bovine & - \\
\hline
\end{tabular}

Key: E=Erkudi; H=Hidmo; M=Male; F=Female; S=Swab; V=Vesicular; SAT-2=Southern African Territories; En = epithelial tissue where, $n=1,2, \ldots, n$

\section{Molecular Detection of FMD Virus}

The extracted RNA from all 27 FMD suspected clinical samples was detected using conventional RT-PCR method and specific primers [22]. This conventional RT-PCR was employed for the amplification and detect the genetic material of the disease in collected clinical samples [23]. All samples were amplified and detected using FMDV universal primers (FMDV7F/FMDV7R). Out of 27 samples detected, only 12 FMDV clinical samples were found to be FMDV positive (DNA bands on gel electrophoresis around 328 bp) as indicated (Figure 2).

\section{Discussion}

The present study was the first in its kind about foot and mouth disease isolation, molecular detection and identifying of the serotype involving in afar region. Foot and mouth disease (FMD) is responsible for 
frequent outbreaks and causes significant economic devastation in the region in particular and on the nation in general. The disease is described by development of typical FMD lesions around the mouth as well as on the foot and unexpected losses of newborn calves $[10,11]$. Occurrence of the disease epidemics is growing livestock problems entirely in all corners of the country. The disease has become one of the most important bottleneck to livestock keepers as result of significant reduction in production and productivity as well as possibly trade restriction in afar region in particular and Ethiopia in general [24-26].

In this research finding, from 18 suspected clinical samples subjected to BHK-21 cell line adaptation, $72.2 \%(n=13)$ field samples showed FMDV induced cytopathic effect (CPE). These cells were appeared as rounding in cells culture, swelling, clumping of the cells as one can demonstrate from (Figure 1). The present study finding was consistent with previous research works such as by [27-29] in which positive sample (CPE) on BHK-21 cells was described by a fast sloughing of the cells. Our study result was in line with study finding by [30], in which infected cells in both study results showed round and sloughing as well as monolayer detachment from the wall of cell culture flask. Other authors such as [31] also described that FMDV isolated from clinical samples and inoculated on BHK-21 cell-culture results in infected-cell that showed specific CPE within 24-48 hours post infection was characterized by rounding of cells and distortion of the monolayer and cell detachments. The remaining samples did not show CPE; this could be due to loss of our samples through shipping from sample collection site to laboratory.

Ethiopia is one of the FMD endemic countries in the horn of Africa, with almost five serotypes prevailing so far. Cumulative research reports in Ethiopia on FMDV serotypes revealed that this disease occurrence is due to any of 0, A, C, SAT-2, and SAT-1 as diagnosed by clinically, serologically, virologically and molecular techniques during the period 1981-2018 [3, 20]. In our study result, serotyping of FMDV results disclosed that the identified serotype SAT-2 (100\%) FMD virus was circulating in Aba'ala district of afar region. This could be to mean that serotype SAT-2 is vastly prevailing and the foremost serotype responsible for frequent outbreaks in the study area of afar region, Ethiopia. In support of this study findings, studies conducted by $[3,13,26,32]$, who reported that serotype SAT-2 virus in Borean pastoral area, Benishangul-Gumuz, Gambella, Addis Ababa and Adama, respectively. Moreover, serotype SAT-2 was previously reported from many sub-saharan African countries [33, 34] described the endemicity of this serotype in these countries. Studies conducted in Uganda indicated that SAT-2 serotype was the most prevalent serotype accountable for the disease occurrence [35]. Another FMDV Serotyping study results in Chad in 2016 showed SAT-2 was the dominant serotype during its study period followed by serotype $O$ [36]. Furthermore, the International Organization for Animal Health (OIE) FMD disease occurrences report in Africa continent since 2000-2010 disclosed that SAT-2 was escalating as an important serotype (41\%) followed by 0 serotype (23\%) [37]. Multi-topotype SAT-2 endemicity and outbreaks out of the Sub-Saharan terrestrial ranges have also been observed in countries south of the Sahara desert, and the Northern African and the Middle East region such as Libya, Egypt, Palestinian Autonomous Territories (PAT), and Bahrain [38]. 
In this study, out of 27 clinical samples detected using conventional PCR for the presence of FMDV genetic material in the sample, only $44.4 \%(n=12)$ were found to be positive. Of these 12 samples detected as positive for FMDV, bovine epithelial tissues were accounted for $22.2 \%(n=6)$ and had the lower $\mathrm{Ct}$ values which could indicate higher concentrations of the virus in these samples. Our results also showed that bovine vesicular fluid samples were accounted for $14.5 \%(n=4)$ and swab samples were accounted for $7.4 \%(n=2)$. This study finding confirmed that the existence of more FMD viral RNA in the epithelial tissues samples as compared to vesicular and swab samples. This study finding is supported by OIE [18] as this institution described epithelial tissues are the ideal samples for virus detection. This was also justified by the fact that reduced samples of conventional RT-PCR positive samples and small samples yielding infectious virus might have been because of virus destruction in the course of transfer from the field. The presence of SAT-2 serotype in the present study district would be as result of uncontrolled cross-border movement of animals intended for pursuit of feed and water and also free trade in livestock among neighboring regions and countries since SAT-2 is widespread to various neighboring countries[39-41].

\section{Conclusions}

The present study finding indicated that FMDV is prevalent in the study area of afar region as confirmed by clinically, serologically, virologically and molecular techniques particularly in the in the study area of the region and serotype SAT-2 was the causality for the outbreaks of the disease in the study area. The occurrence of this disease is a foremost badly behaved for the improvement of the livestock industry as it causes enormous worldwide harms of livestock sector as well as severe impacts on export earing from national and international trade thereby threaten the living means of livestock keepers in particular and income source of the country in general. Out of the serotypes identified in our country, the identified prevailing serotype was SAT-2 that causes frequent outbreaks in the study area of afar region, Ethiopia. Region wise regular FMD outbreaks investigation to have more full information about the serotypes, topotypes involving in the region and vaccine matching studies of field isolates to evaluate vaccine protection potential has paramount important for effective vaccine development.

\section{Methods}

\section{Description of the study areas}

This research work was implemented in Aba'ala district (Erkudi and Hidmo kebeles), which is located in afar region, Ethiopia. This study district was purposively selected for the reason that the presence of active FMD outbreak case report in the course of the study period, January, 2019 to March, 2020. Afar regional state shares joint intercontinental borders with Eritrea in the north-east and Djibuti in the east part of the region. The region is described specifically through arid and semi-arid weather conditions with low and unpredictable rainfall. The altitude of the region ranges from $120 \mathrm{~m}$ below sea level in Danakil depression to $1500 \mathrm{~m}$ above sea level. Majority of the pastoral community mainly depend on livestock production for their livelihood. According to APADB (2006), approximately there are 1.9 million cattle 
population in the region, and $90 \%$ of the study animals are managed under pastoral production and the rest $10 \%$ in agro-pastoral production system. The study area is situated in the North area of the region, Northeastern Ethiopia. It lies around between $13^{\circ} 15^{\prime}$ and $13^{\circ} 30^{\prime} 1$ atitude and $39^{\circ} 39^{\prime}$ and $39^{\circ} 55^{\prime}$ longitude. The high temperature of afar ranges as of $25^{\circ} \mathrm{C}$ in case of rainy period to $48^{\circ} \mathrm{C}$ during the dry season [42].

\section{Study Population}

The study populations were cattle that had experienced outbreak cases of FMDV and manifested typical FMD clinical signs in the Aba'ala district area during the study period of this research work. The study animals were cautiously inspected for the manifestation of distinguishing clinical signs of FMD such as vesicular lesions around the oral cavity, on the feet, salivation, lameness, anorexia and rise in temperature [43]. All ages and sexes of the study population reared by agro-pastoralists in the outbreak affected kebeles (subunits) of the study district were sampled.

\section{Study Design}

Prior to field level investigation and sample collection, district and kebele level animal health expertises were informed to report for regional veterinary laboratory centers when FMD outbreak occurred. Therefore, based on the occurrence of active FMD outbreak case report and active outbreak finding, a cross sectional study was used to collect tissue samples. Clinically, FMD suspected study populations were physically inspected for the manifestation of FMD with typical signs were sampled to collect biopsy samples that were intended for viral isolation, molecular detection and serotype identification purpose.

\section{Sampling techniques and Sample Size Determination}

Purposive sampling method was employed to select FMD affected study district, cattle herds, sampling animals as a result of the occurrence of FMD active case reports in the course of the study period, January, 2019 to March, 2020. Accordingly, within the study areas (subunits) animals with clear signs, symptoms and suspected to be infected with FMDV as indicated in (figure 3) were selected and sampled. From all outbreak affected kebeles, 27 swab, epithelial tissue and vesicular fluid samples were collected from clinically FMD suspected animals with active outbreak lesions for cell culture based virus isolation, molecular detection and identification of serotypes circulating in the study district.

\section{Sample Collection and Transportation}

Representative active bovine epithelial tissues, vesicular fluid and swab samples were aseptically collected with the help of tissue forceps from un-ruptured and freshly ruptured vesicles of clinically affected animals during the course of field outbreak to isolate the circulating viruses responsible for the occurrence of disease. These collected FMD suspected samples were kept in a sampling bottle containing virus transport medium that has equal volume of $0.04 \mathrm{M}$ phosphate buffer saline (PBS) with $50 \%$ glycerol enriched by antibiotics and antifungal according to the protocol recommended by OIE [18]. Collected clinical FMDV suspected specimens were transported to laboratory and stored at $-20^{\circ} \mathrm{C}$ and got 
transportation to National veterinary institute $(\mathrm{NVI})$ using cold chain for virus isolation, molecular detection and serotype identification purpose.

\section{FMD Virus Isolation}

The samples collected were processed and cultured on BHK-21 cell monolayer with three subsequent passages as follows. About $1 \mathrm{gram}$ of each tissue was taken and washed three times using sterile phosphate buffered saline containing antibiotics and antifungal (PBS) on petridish. Then, washed tissues were transferred to sterile mortar, cut into pieces using scissor and minced by scalpel blade. These minced tissues were then grounded and homogenized in sterile sand with a sterile pestle and mortal. Nine $\mathrm{ml}$ of PBS was added to the homogenized tissues and well mixed as well as small volume tissue culture made and small amount of five percent antibiotics (penicillin, streptomycin and Amphotericin B solution) containing medium were added so that the final volume was ten times that of the epithelial tissue, producing of ten percent suspension [18]. All procedures were conducted under the Biosafety cabinet level 2. About $1 \mathrm{ml}$ of filtered tissue suspension was inoculated on confluent cultured Baby hamster kidney (BHK-21) monolayer cells grown on $25 \mathrm{~cm}^{2}$ tissue culture flasks and incubated at $37^{\circ} \mathrm{C}$ for $1 \mathrm{hr}$ for adsorption of the virus. Then, cell cultures were added $8 \mathrm{ml}$ of maintenance medium ( $2 \% \mathrm{MEM})$ and incubated at $37^{\circ} \mathrm{C}$ and $5 \% \mathrm{CO} 2$ in a humidified incubator. The appearance of virus induced cytopathic effect (CPE) was observed daily under the inverted microscope. The inoculated cell line was harvested when $85-100 \%$ of CPE was observed. These infected cells did not show CPE within $72 \mathrm{hrs}$ post infection on the third passage were supposed to be virus negative $[18,44]$. Samples that showed typical CPE (positive cases), clinical tissue materials were used for serotype identification of the virus involved in the outbreak cases using antigen detection sandwich ELISA [45].

\section{Serotyping of FMD Virus Isolates}

FMD Serotyping was executed using both antigen detection sandwich ELISA and sets of serotype specific primers intended for testing of FMD virus and identifying the serotypes responsible for outbreaks cases. Sandwich-ELISA was executed with particular combinations of anti-FMDV monoclonal antibodies (MAb), used as coated and conjugated antibodies. The kit was developed for detection and serotyping of FMDV O, A, C, SAT1 and SAT2. A pan-FMDV test, detecting any isolates of O, A, C, Asia1 and SAT serotypes, was also included in the kit to complement the specific serotyping of FMDV. The test was implemented based on the manufacturer's instruction and OIE [46]. A total of 13 positive sample suspensions that exhibited FMDV cytopathic effect (CPE) on BHK-21 cell were needed to be tested for detection of serotype identification using sandwich ELISA on a microplate containing 96 wells.

About $25 \mu \mathrm{l}$ of dilute buffer was dispensed into all wells of the test plate, then $25 \mu$ l of previously diluted samples using ELISA buffer and ready-to-use controls was dispensed into the appropriate wells of the test plate pre-coated with recombinant FMD viral antibody. One positive control for each FMD types $0, A$, SAT1 and SAT2 and negative controls were included in each plate. The plates were sealed using the enclosed plate sealer and incubated for $1 \mathrm{hr}$ at room temperature $\left(20-25^{\circ} \mathrm{C}\right)$. After incubation, all fluids on 
the plates were discarded and the remaining residual fluids were removed. Then $200 \mu \mathrm{l}$ of washing solution were added and incubated for $3 \mathrm{~min}$ at room temperature, subsequently wells were emptied and the washing repeated twice (three washing cycles in total). Then all residual fluids were removed by tapping on clean absorbent paper and $50 \mu$ l of conjugate. A was added from columns 1 to 8 and the same volume of conjugate $B$ was added from columns 9 to 12. Plates were covered and incubated at room temperature for 1 hour. After incubation $50 \mu \mathrm{l}$ of substrate per well was added to all wells and plates were covered and left at room temperature for 20 minutes in the dark. The reaction was stopped by adding $50 \mu \mathrm{l}$ of stop solution (sulfuric acid (H2SO4)). Immediately after stopping, reading the optical density (OD) of each well was done at $450 \mathrm{~nm}$ wavelength using micro plate reader.

\section{Molecular Detection of FMD Virus}

The presence of FMD viral genetic material in all 27 collected field samples was tested using conventional RT-PCR and specific primers that amplify Viral protein 1 (VP1) of FMDV using the RNeasy Mini Kit following the manufacturer's instruction (Qiagen, USA).

\section{FMD Viral RNA Extraction}

Total RNA was extracted from collected FMD suspected clinical samples suspension using Qiagen RNA extraction kit following manufacturer's instructions as [47]. Briefly, 140 mirco-liters of sample suspension was added to $560 \mu \mathrm{l}$ buffer AVL carrier RNA in the mirco centrifuge and vortexed for 15 second to mix and then incubated at room temperature $\left(25^{\circ} \mathrm{c}\right)$ for $10 \mathrm{~min}$. The tubes were briefly centrifuged to remove drops from the inside of the lid. Then, $560 \mu$ of ethanol (70\%) was added to the sample and mixed by pulse vortexing for 15 seconds followed by centrifuging to remove drops from the inside lid. Then, $630 \mu$ of the solution were applied to the QIAMP Mini-spin column in a $2 \mathrm{ml}$ collection tube and centrifuged $12,500 \mathrm{rpm}$ for $1 \mathrm{~min}$. The filtrate was discarded and the column was placed in a fresh $2 \mathrm{ml}$ collection tube. Then, $500 \mu \mathrm{l}$ of buffer AW2 were added and centrifuged at 12,500 rpm for three min and the filtrate was discarded. Next, $65 \mu$ l of Buffer AVE was added to the column equilibrated at room temperature for one min and centrifuged at 12,500 for $1 \mathrm{~min}$. Using reverse transcription polymerase chain reaction (RT-PCR) and specific primers set FMDV7-forward (FMDV7F) and FMDV7-reverse (FMDV7R) as depicted in (table 1), extracted RNA samples were detected for the presence of FMDV.

Table 1: The Universal primers and thermal cycle used for amplification of FMDV 


\begin{tabular}{|c|c|c|c|}
\hline \multicolumn{4}{|c|}{ 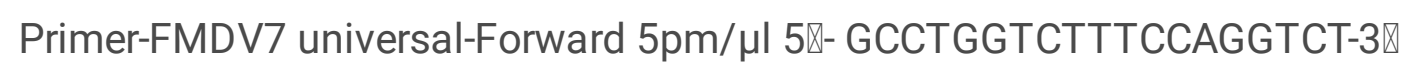 } \\
\hline \multicolumn{4}{|c|}{ Primer-FMDV7universal-Reverse-5pm/ $\mu \mathrm{l}$ 5囚-CCAGTCCCCTTCTCAGATC-3囚 } \\
\hline & Temperature & Time & Cycle \\
\hline Initial denaturation & 95 & $5 \mathrm{~min}$ & 1 cycle \\
\hline $1^{\text {st }}$ denaturation & 94 & $1 \mathrm{~min}$ & \multirow{3}{*}{35 cycles } \\
\hline Annealing & 54 & $1 \mathrm{~min}$ & \\
\hline Elongation & 72 & $1 \mathrm{~min}$ & \\
\hline Final elongation & 72 & $10 \mathrm{~min}$ & 1 cycle \\
\hline
\end{tabular}

\section{Agarose Gel Electrophoresis}

The PCR products were analyzed on the prepared 1.5\% Agarose gel by adding $4 \mu$ l gel red with loading dye and then the PCR product were loaded in the volume of $10 \mu \mathrm{l}$ in each well and $10 \mu \mathrm{l}$ molecular marker (ladder) was added started 100bp plus. Electrophoresis was run for one hour at 120V. Then, the DNA band was visualized by UV illumination, using desktop according to the base pair (bp), and then the size was determined and documented.

\section{Data Management and Statistical Analysis}

Data generated from laboratory investigations were recorded and coded using Microsoft Excel spreadsheet and analyzed using STATA version 14.2 for Windows. Cell culture results, CPE development and molecular characterization results were recorded and tabulated. Virus isolation and molecular detection of FMD virus were elaborated using descriptive statistics analysis. Moreover, regarding the molecular characterization, the banding patterns of individual sample were scored based on the presence or absence of the bands with the appropriate base pairs.

\section{Abbreviations}

CSA: Central Statistical Authority; FAO: Food and Agriculture Organization; FMD: Foot and Mouth Disease; FMDV: Foot and Mouth Disease Virus; GDP: Growth Domestic product; NVI: National Veterinary Institute; OIE: World Health Organization for Animal Health; SAT: Southern African Territories; TD: Teshager Dubie; TA: Tsedale Amare.

\section{Declarations}


Written ethical approval and consent for this study was obtained from Samara University College of Veterinary Medicine of Animal Research Ethics and Review committee (Ref/AREC020/2019). All efforts were made to minimize animal suffering during sample collection. Informed oral consents were obtained from all animal owners who participated in the study to take samples from their cattle and for further research use of the samples. These written and oral consents were documented.

\section{Consent for publication}

Not applicable

\section{Availability of data and materials}

The data sets used and/or analyzed during the current study available from the corresponding author on reasonable request.

\section{Competing interests}

The authors declare that they have no competing interests in the publication of this paper.

\section{Funding}

This research work was financially supported by Samara University, Research and Community Service Office and the funder had no role in the design and execution of this study, sample collection, data analysis, interpretation of the data and writing the manuscript.

\section{Authors' contributions}

TD: Contributed to conception of the research idea, designing and data collection, data analysis, interpretation of data, writing and editing of the manuscript. TA: Contributed to Sample collection, data analysis and reviewing of the manuscript. All authors read and approved the final manuscript.

\section{Acknowledgments}

The authors would like to thank Research and Community service office of Samara University for funding this research project and National Veterinary Institute-Ethiopia for the provision of laboratory facilities and space to execute this research work. We would like to extend our thanks to herd owners for their cooperation in the study areas during sample collection.

\section{References}

1. CSA FDRoE: Central Statistical Agency: Agricultural Sample Survey 2017, CSA, Addis Ababa, Ethiopia. In.; 2017. 
2. Behnke R, Metaferia F: The Contribution of Livestock to the Ethiopian Economy -Part II. IGAD LPI Working Paper No. 02-11. 2011.

3. Ayelet G, Mahapatra M, Gelaye E, Egziabher G, RufealT, Sahle M: Genetic characterization of footand-mouth disease viruses Ethiopia 1981-2007. J Emerg Infect Dis 2009, 16(9):1409-1417.

4. Abdela N, : Sero-prevalence, risk factors and distribution of foot and mouth disease in Ethiopia. Acta Tropica 2017, 169:125-132.

5. Asresie A, Zemedu L: Contribution of livestock sector in Ethiopian economy: A review Advances in Life Science and Technology 2015.

6. Bayissa B, Ayelet G, Kyule M, Jibril Y, Gelaye E: Study on seroprevalence, risk factors, and economic impact of foot-and-mouth disease in Borena pastoral and agro-pastoral system, Southern Ethiopia. Tropical Animal Health Production 2011, 43:759-766.

7. Ganeshkumar B: Economic Impact of Foot-and-Mouth Disease in India, Scientific Developments and Technical Challenges in the Progressive Control of Foot-and-Mouth Disease in South Asia, New Delhi, India. Glob Res Alli 2012, 13:5.

8. OIE: Manual of Diagnostic Tests and Vaccines for Terrestrial Animals. Lumpy skin disease. 2010, 2(4):768-778.

9. Mansley LM, Donaldson Al, Thrusfield MV, Honhold N: Destructive tension: mathematics versus experience-the progress and control of the foot and mouth disease epidemic. Rev sci-entifique et tech 2011, 30:483-498.

10. Quinn PJ, Markey BK, Carter ME, Donnelly WJ, Leonard F: Veterinary microbiology and microbial disease: Blackwell Science Ltd, A Blackwell publishing company; 2005.

11. OIE: Foot-and-mouth disease, Manual of Standard for Diagnostic Tests and Vaccine for Terrestrial Animals, 6th ed. Paris. 2009:156-212.

12. Knight-Jones TJD, Rushton J: The economic impacts of foot and mouth disease - what are they, how big are they and where do they occur?. Prev Vet Med 2013, 112:161-173.

13. Tefera L: Sero-Prevalence, Involvement of Small Ruminants in the Epidemiology of FMD, and Characterization of FMD Virus Circulating in the Study Area and Assess Epidemiological Risk Factors Associated with FMD in Cattle in Selected Districts of Gambella Region, Ethiopia. Master's Thesis, Faculty of Veterinary Medicine, Addis Ababa University, Debre Zeit, Ethiopia. 2010.

14. Mohamoud A, Tessema E, Degefu H: Sero-prevalence of bovine Foot and mouth disease (FMD) in Awbere and Babille districts of Jijiga zone, Somalia Regional State, Eastern Ethiopia. African J Microbio Res 2011, 5(21):3559-3563.

15. Jenbere $\mathrm{S}$, Etana $\mathrm{M}$, Negussie $\mathrm{H}$ : Study on the risk factors of foot and mouth disease in selected districts of afar pastoral area, Northeast Ethiopia. J Anim Vet Adv 2011, 10(11):1368-1372.

16. Vosloo W, Bastos DS, Sangare O, Hargreaves SK, Thomson R: Review of the status and control of foot and mouth disease in sub-Saharan Africa. Rev Sci Tech 202, 21:437-449. 
17. Negussie H, MosesKyule N, Yami M, Ayelet G, Jenberie T: Outbreak investigations and genetic characterization of foot and mouth disease virus in Ethiopia. Trop Anim Health Prod 2011, 43:235243.

18. OIE: Manual of Diagnostic Tests and Vaccines for Terrestrial Manual: 7th edition, volume I. Version adopted by the World Assembly of Delegates of the OIE, Paris, France. 2012:1401-1405.

19. Rufael T, Catley A, Bogale A, Sahle M, Shiferaw Y: Foot and mouth disease in the Borana pastoral system, southern Ethiopia and implications for livelihoods and international trade. Trop Anim Health Prod 2008, 40:29-38.

20. Jemberu WT, Mourists MCM, Sahle M SB, Vernooiji J, Hogeveen H: Epidemiology of Foot and Mouth Disease in Ethiopia: Aretrospective anlaysis of Distric Level Outbreak, 2007-2012. Trans Emerg Dis 2015, 63:246-259.

21. Yang M, Goolia MW, Bittner $\mathrm{H}$, Clavijo A: Development of a quick and simple detection methodology for FMD virus serotypes O, A and Asia 1 using a generic rapid assay devie. Virol J 2013, 10:125.

22. Callahan JD, Brown F, Osorio FA SJ, Kramer E, , Long W: Use of portable real time reverse transcriptase polymerase chain reaction assay for rapid detection of FMD virus. J Am Vet Med Assoc 2002, 220(11):1636-1642.

23. Amarel M, Owen N, Ferris N, Kitching R, Doel R: Detection of foot and mouth disease viral sequences in clinical specimens and ethyleneimine inactivated preparations by the polymerase chain reaction. Vaccine 1993, 11:415-421.

24. Wagari A: Seroprevalence of foot and mouth disease in bulls of borane origin quarantined in adama. Int J Biochem Biophys Mol Biol 2016, 1(1):1-10.

25. Belina D, Girma B, Mengistu S: Sero-prevalence of bovine foot and mouth disease in selected Districts of Eastern Showa Zone, Oromia Regional State, Ethiopia. Glob J Sci Front Res 2016, 16:4.

26. Sulayeman M, Dawo F, Mammo B, Gizaw D, Shegu D: Isolation, molecular characterization and seroprevalence study of foot-and-mouth disease virus circulating in central Ethiopia Veterinary Research 2018, 14:110.

27. Huang $\mathrm{X}$, Li Y, Fang H, Zheng C: Establishment of persistent infection with foot and mouth disease virus in BHK-21 cells. Virol J 2011, 14:169.

28. Haileleul N, Gelagay A, Shiferaw J, Liyuwork T: Molecular epidemiology and vaccine matching study on foot and mouth disease virus circulating in Ethiopia. African J Microbiol Res 2013, 7:5101-5106.

29. Yeneneh $\mathrm{T}$ : Isolation, molecular characterization and vaccine matching of foot-and-mouth disease virus circulating in Ethiopia. MSc Thesis, Addis Ababa University, college of Veterinary Medicine, Bishoftu, Ethiopia.; 2014.

30. Tesfaye A, Sehale M, Abebe A, Muluneh A, Gizaw D: Sero-prevalence of foot and mouth disease in cattle in Borena Zone, Oromia regional state, Ethiopia. Ethiop Vet J 2016, 20(1):55-66.

31. Shawky M, Abd A, Fakry M, Daoud HM, Ehab ES, Wael MG, Rizk SA, Mohamed A, Farouk M: Isolation and Molecular Characterization of Foot and Mouth Disease SAT-2 Virus during Outbreak 2012 in Egypt. J Vet Adv 2013, 3(2):60-68. 
32. Gelaye E, Beyene B, Ayelet G: Foot and mouth disease virus serotype identified in Ethiopia. Ethiopian Vet J 2005, 9:75-79.

33. Sangare 0: Molecular epidemiology of foot and mouth disease virus in West Africa. PhD Thesis. University of Pretoria. Pretoria, South Africa. 2005.

34. Sahle M, Dwarka RM, Venter EH, Vosloo W: Comparison of SAT-1 FMD virus isolates obtained from East Africa between 1971 and 2000 with viruses from the rest of sub-Saharan Africa. Arch Virol 2007, 152:797-804.

35. Belina D, Girma B, Mengistu S: Sero-prevalence of bovine foot and mouth disease in selected Districts of Eastern Showa Zone, Oromia Regional State, Ethiopia. Glob J Sci Front Res 2016, 16(4).

36. Arada IAA, Aurore R, Anthony R, Kamila G, Raphaelle M, Facundo M, Sandra BB, Renaud L: Seroprevalence and molecular characterization of foot-and-mouth disease virus in Chad. Wiley Vet Med Sci 2020, 6:114-121.

37. Maree FF, Blignaut B, Esterhuysen JJ, Dde Beer TAP, Theron J, Rieder E: Predicting antigenic sites on the foot-and-mouth disease virus capsid of the South African Territories types using virus neutralization data. J Gen Viro/ 2011, 92:2297-2309.

38. Mouton L, Dekker A, Bleijenberg M, Blanchet M, Coco-Martin J, Hudelet P, Goutebroze S: A foot-andmouth disease SAT2 vaccine protects swine against experimental challenge with a homologous virus strain, irrespective of mild pathogenicity in this species. Vaccine 2018, 36:2020-2024.

39. Bertram MR, Bravo C, De Rueda R, Garabed SD, Jumbo MM, Pauszek S, Arzt J: Molecular epidemiology of foot-and- mouth disease virus in the context of transboundary animal movement in the far North Region of Cameroon. Frontiers in Veterinary Science 2018, 5:320.

40. Bertram MR, Delgado A, Pauszek SJ, Smoliga GR, Brito B, Stenfeldt C, Arzt J: Effect of vaccination on cattle subclinically infected with foot-and-mouth disease virus in Cameroon. Preventive Veterinary Medicine 2018, 155:1-10.

41. Souley Kouato, Kris De Clercq, Emmanuel Abatih, Fabiana D, Donald PK, Eric T, Hamani M, Saegerman C: Review of epidemiological risk models for foot-and-mouth disease: Implications for prevention strategies with a focus on Africa. PLOS ONE 2018, 35.

42. Afar Pastoral, Agricultural, Development B: Baseline survey made on the Potential, Constraints, and Opportunity on the Production System of 29 districts of Afar National Regional State In.; 2006.

43. Menda S, Jenberie Shi, Negusssie H, Ayelet G: Molecular serotyping of foot and mouth disease outbreaks in Ethiopia. African J of Microbio Res 2014, 8(29):2754-2757.

44. Ding YZ, Chen J, Zhang JH, Zhou LN, Ma L, Zhang Y: An overview of control strategy and diagnostic technology for foot-and-mouth disease in China. Virol $J$ 2013, 10:78.

45. Bhattacharya S, Pattnaik B, Venkataramanan R: Development and application of sandwich enzymelinked immunosorbent assay (ELISA) for type identification of foot-and-mouth disease virus in direct field materials. Indian J of Ani Scie 1996, 19:1-9.

46. OIE: Foot-and-Mouth Disease. In Terrestrial Animal Health Code (8.8.). Retrieved from http://www.oie.int. 2016. 
47. Kafeero H, Frank M, Mwiine N, Kalenzi A, Nanteza A: Comparative detection of FMD virus by reverse transcription loop mediated isothermal amplification assay and real time polymerase chain reaction in Uganda. Int $J$ of Biotech and Food Science 2016, 4:22-33.

\section{Figures}

A

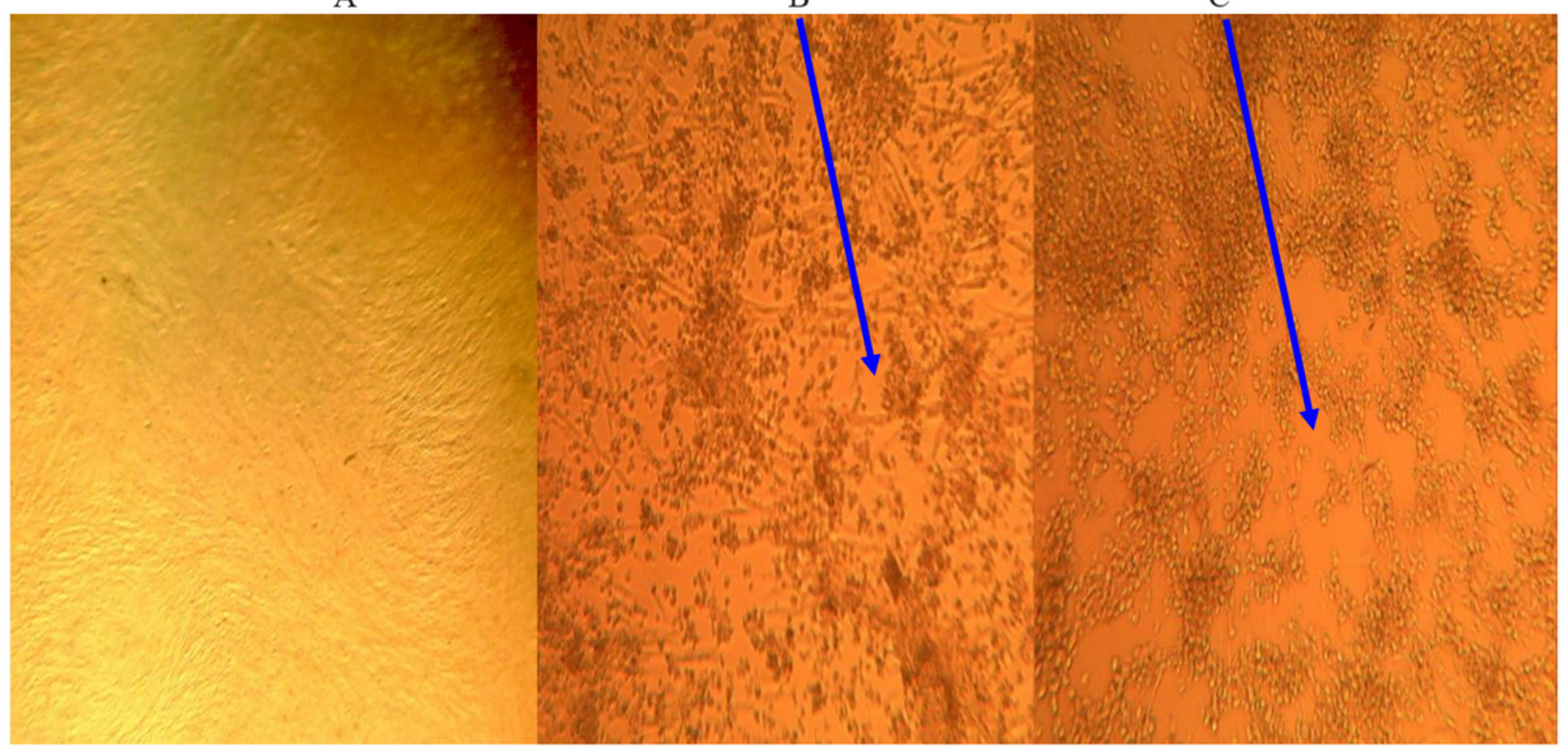

\section{Figure 1}

Picture taken during infectious FMDV virus isolation. A: BHK21 cell control (cell without FMDV infection), $B$ and C: showed virus induced cytophatic effect (indicated by arrow) inoculated with FMDV outbreak isolates. 


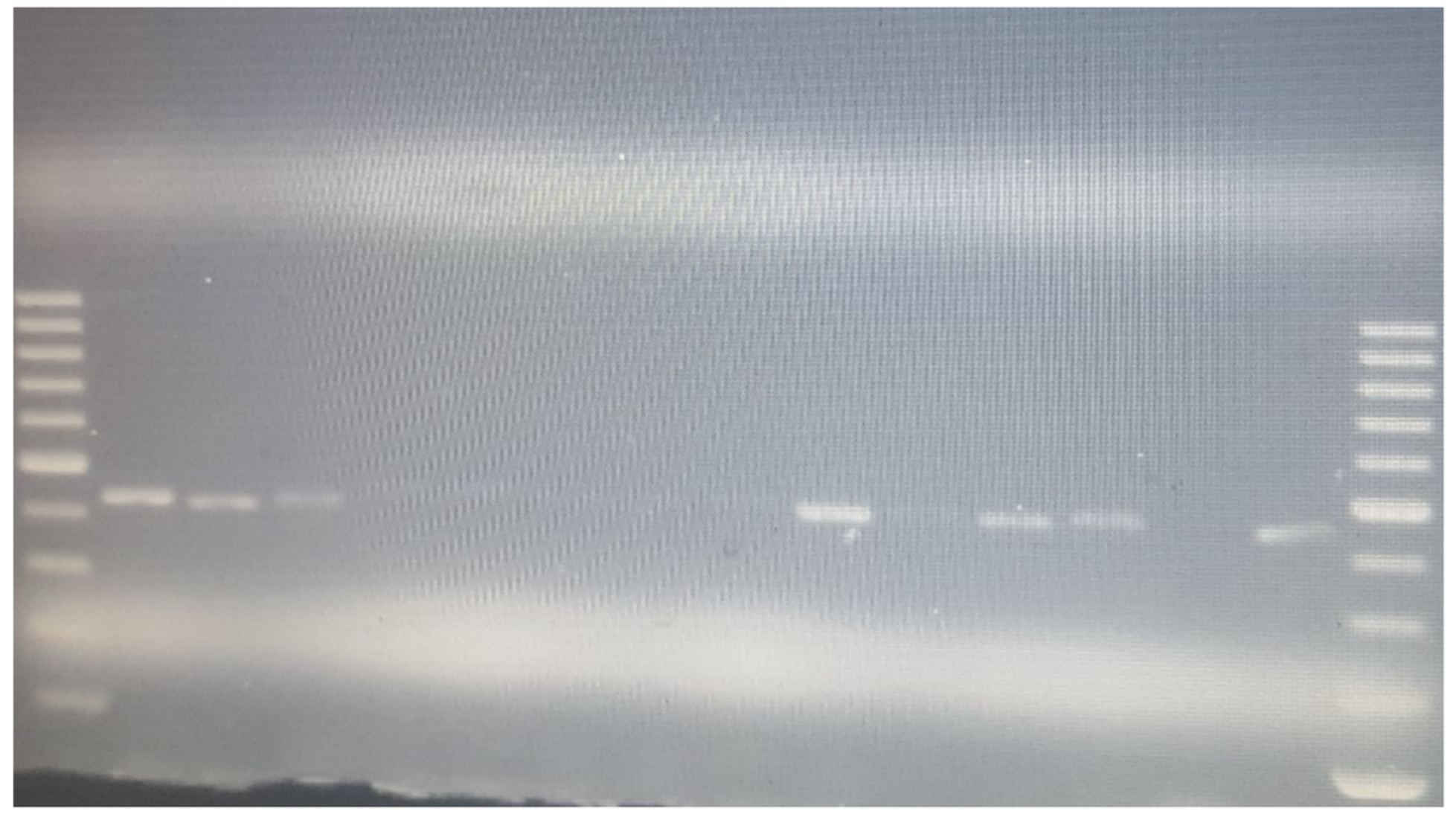

\section{Figure 2}

Detection of FMDV genome by RT-PCR using primer mixture of FMDV7F/ FMDV7R was used targeting

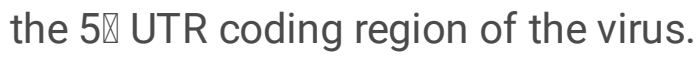




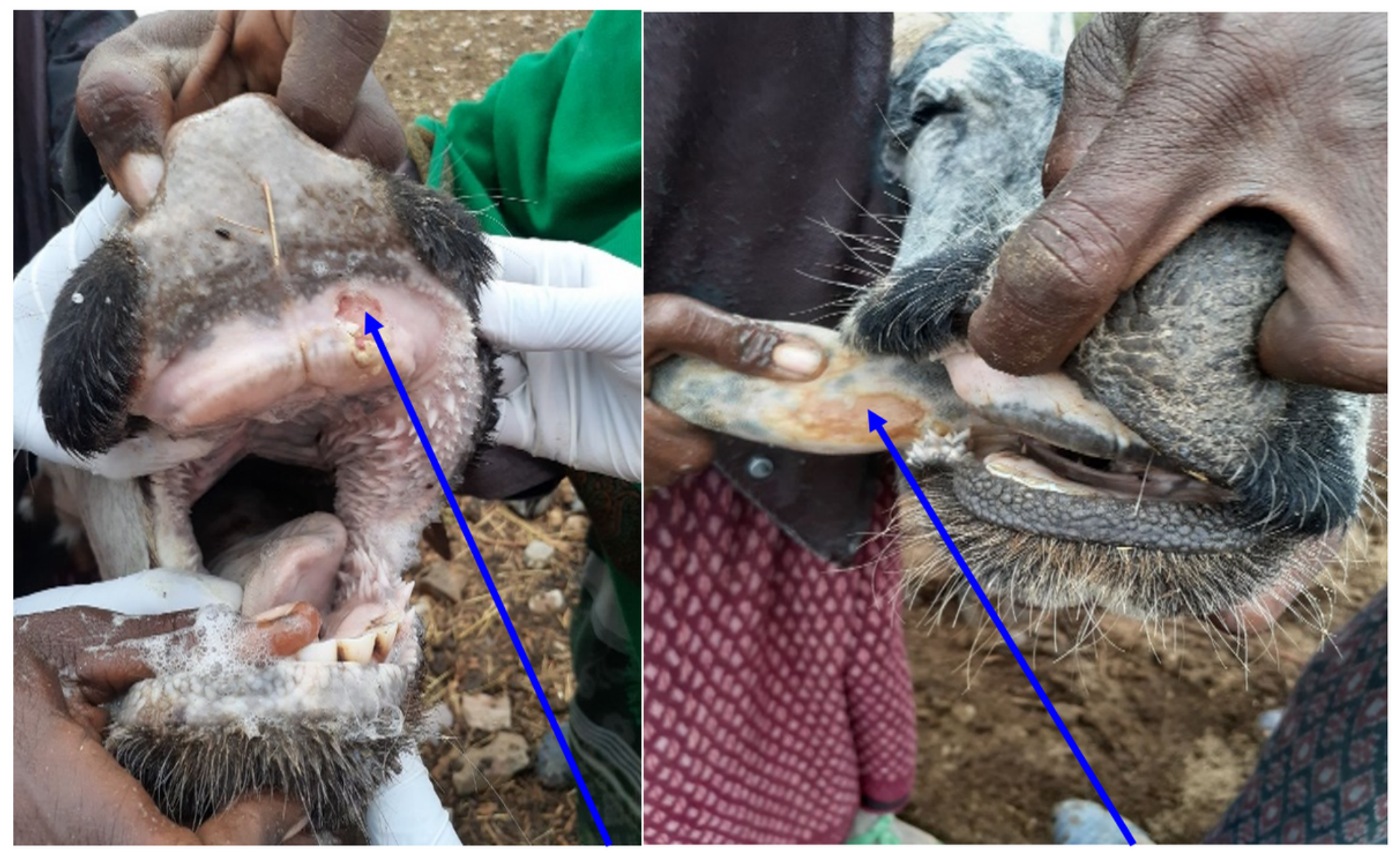

Figure 3

Gum and tongue lesion observed on cattle infected with Foot and Mouth disease 